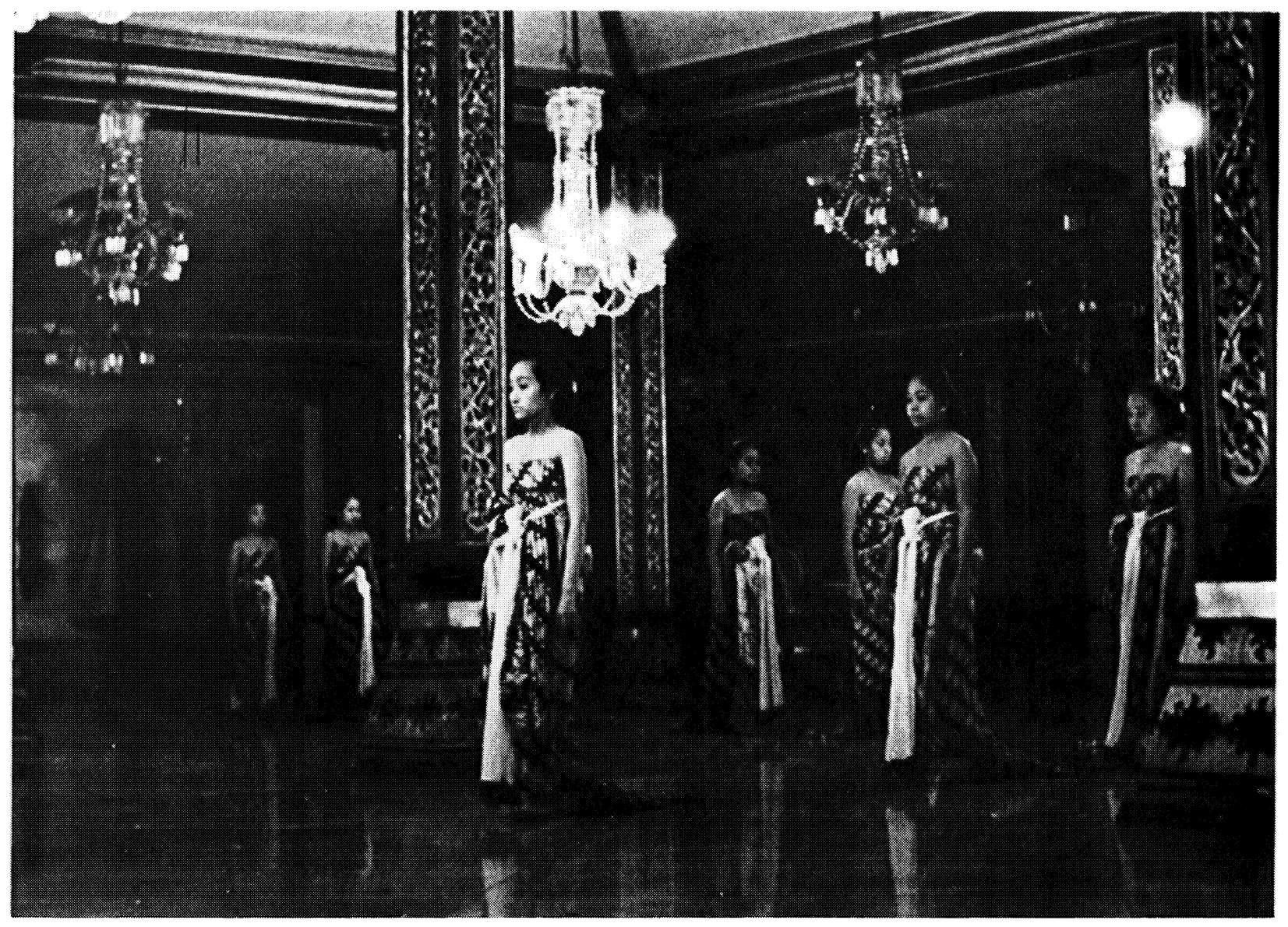

P1. 1. Dress Rehearsal (kirap). The beḑaja dancers appearing in a single file from the Dalem Prabasujasa. 


\section{A BEDAJA KETAWANG DANCE PERFORMANCE \\ AT THE COURT OF SURAKARTA}

Nusjirwan Tirtaamidjaja

Unlike the Court of the Sultan of Jogjakarta, which as early as 1918 permitted its bedaja dances to be performed outside the palace walls, the Surakarta Kraton still considers these dances its sole prerogative. It is this very exclusiveness which now threatens many of the Surakarta Kraton dances with extinction. Many of the court musicians are aged and the number of dancers is rapidly dwindling.

In an attempt to document and record the rich dance tradition of the Kraton of Surakarta, the author in 1962 was granted permission by H.H. Sri Susuhunan Pakubuwana XII to undertake research inside the palace. It is hoped that this eyewitness report, supplemented with some illustrations and comments, will help to open the Court of Surakarta to scientific research by Indonesian as well as foreign scholars.

The first part of this article contains some preliminary information on the bedaja dances in general and the Bedaja Ketawang dance in particular. The second part describes the Beţaja Ketawang dance as it was performed during the weeklong rehearsals and on the anniversary commemorating the susuhunan's accession to the throne, celebrated on November 15, 1966. Part three contains some illustrations, choreographical positions of the Bedaja Ketawang and, as appendices, a list of offerings and litanies.

Every year on the second day of the month. Ruwah by the Javanese calendar, the Kraton of Surakarta commemorates the accession to the throne of the present head of the Royal Family, H.H. Sri Susuhunan Pakubuwana XII. The celebrations consist of various ceremonies, culminating in a performance of the sacred Bediaja Ketawang dance.

Although very little is known about the origin and meaning of the word bedaja, the bedaja dances are considered to be among the oldest of Javanese dances. Of the existing Javanese courts, it is the court of the Susuhunan of Surakarta and the Sultan of Jogjakarta which have original bedaja dance repertoires, while lesser courts like the Mangkunegaran in Surakarta and the Paku Alaman in Jogjakarta introduced the dances as a 
result of dynastic marriages with the two already mentioned principal courts. In the past other courts of Java may have had their bedaja dances, but today very little is left of that tradition. ' It is also possible that courts outside the island of Java, which at one time or another were under Javanese influence, also had their bedaja, but there is little certainty about this.

Up to now, only the brief remarks of visiting foreigners at the courts of Java have given us a glimpse of bedaja dances. ${ }^{2}$ Scholarly research was not begun until the early twenties and even then only in a rather superficial way. Some noteworthy exceptions of course exist. ${ }^{3}$ Hopefully the opening of the royal archives will throw more light.

According to the Surakarta tradition ${ }^{4}$ the most sacred dance of all is the Bedaja Ketawang. It originates from the reign of Sultan Agung of Mataram (1916-1645). Legend has it that this dance is closely connected with the Indian Ocean (Seganten Kidul), because the founder of the Mataram dynasty, (Panembahan Sénapati Ingalaga on Wong Agung Ngeksiganda) often meditated on its shores in order to receive divine inspiration from the Goddess of the South Sea (Kandjeng Ratu Kidul). On one occasion the King visited her palace Saka Domas Balé Kentjana, which lies at the bottom of the ocean. The Goddess fell in love with

1. A dance performance was held at the Kraton Kanoman in Tjirebon in 1964. The dance, called rimbé, was performed by nine girls. One wonders whether this could be a bedaja dance performance. See also Cultureël Nieuws, Indonésië, (1952), Vol. 21-22, p. 428, which mentions the regent of Sukapura ( Tjiamis, West Java), who had bedaja dancers.

2. See Rijcklof van Goens, Javaense Reyse, gedaen van Batavia over Samarangh na de Konincklijcke Hooft-plaets Mataram. Door de Heere N.N. in den Jare 1656, p. 15-16. Sir Thomas Stamford Raffles, History of Java, (1817), Vol. I, p. 342. E. Hardouin, Java, $(1872)$, P. 145-147. J. Groneman, Javaanse Toneeldansen, (1883). Donald MacLaine Campbell, Java: Past \& Present, (18??), Vol. II, P. 1024-1027.

3. See G.P.H. Hadiwidjaja, De Bedojo Ketawang, (1919), publication issued by the Java Instituut; Mrs. Van HelsdingenSchoevers, Het Serimpiboek, (1925), whose book was intended as a standard work on the Surakarta court dances. (Due to the untimely death of the author the book was never finished.); Th. Pigeaud, Javaanse Volksvertoningen, (1938), especially section 474 on the Bedaja Ketawang.

4. See the bulletin issued by the Kraton of Surakarta as a programme for the foreign guests on November 15, 1966 (the anniversary of the accession to the throne). 
the handsome King and expressed her feelings by dancing and singing in front of him. This story inspired sultan Agung of Mataram, a direct descendant of Panembahan Sénapati, to create the bedaja dance known as the Bedaja Ketawang.

It is also said that when the Goddess danced she was dressed unlike any other dancer, surpassing all in beauty and loveliness. This may explain why to this day the Bedaja Ketawang dancers are dressed like brides, wearing the esoterically designed Dodot Banguntulak Alas-alasan. Dark blue in color with a white diamond-shaped center, it is decorated all around with gold leaf glued on in patterns symbolizing animals of the forests, mountains and oceans. 5

Because of its connection with the greatly dreaded Goddess of the South Sea, people inside as well as outside the palace walls are reluctant to give information about the Bedaja Ketawang. They are fearful of terrible consequences if an article is written or a photograph taken. They also believe that on certain occasions the Goddess herself appears as one of the dancers and if angered will take a dancer with her to her palace at the bottom of the ocean.

Beçaja dances are generally performed only on solemn occasions such as the anniversary of the ruler's accession to the throne, or in honor of visiting royalty. The dancers, nine in number, are either female relatives of the ruler or specially chosen ladies-in-waiting. The sacred character of the dances is revealed in part by the offerings presented, the burning of incense before and during the whole performance, as well as the strict fasting observed by the dancers for at least twelve hours before their appearance. This abstinence is meant to purify body and mind. Purity of body is also evident in the rule that a dancer who happens to be having her menstrual period is barred from taking part in the rehearsals as well as in the full Bedaja Ketawang performance. If it occurs that the required minimum of seven dancers can not participate because of the above mentioned impediment, a female court attendant will go to the meditation chamber (sanggar pamudjan) to inform the Goddess that the rehearsal cannot take place.

Actually dances like the Beḑaja Ketawang are not simply religious ceremonies. In the course of time they have become symbols of the highest authority in the kingdom, equal in rank to the sacred state regalia. As a consequence only the principal courts of Java had full-scale bedaja performances featuring nine dancers, while princes of lesser rank were only

5. This particular design is said to symbolize the earth, the oceans, light and darkness. 
permitted seven. 6

The beauty of a full bedaja performance lies in the subtle harmony and counterpoint built up between the gamelan orchestra, the choir and the intricate choreography. The dances consist primarily of languid movements accentuated by flicks of long sashes and gentle kicks with long, swirling trains. Although the dance itself has no plot or story to tell, the litany sung by the female choir conveys the essential meaning of the whole ritual.

A bedaja dance takes its name from the melody played by the gamelan. Sultans and princes have been known to be so moved by a particular melody or composition that they have "commissioned" a bedaja for it. From the music one can often get some idea as to the antiquity of a particular dance. The older bedaja, for example, make use of an archaic instrument, called the kemanak, as well as a distinctive singing style, known as mandaraka. Both the instrument and the singing style are mentioned in written sources dating back to the kingdom of Kediri (East Java), which flourished from the 1lth to the 13th century A.D.7 The hypnotic bell-like sound of the kemanak and the almost Gregorian mandaraka chanting produce an effect utterly different from modern gamelan music.

II

Preparations for the anniversary commemorating the accession to the throne of Susuhunan Pakubuwana XII in 1966 started a week before November 15. Rehearsals for the Bedaja Ketawang dance, usually held only once in 35 days on the afternoon of the auspicious Anggarakasih day of the Javanese calendar, were held every evening from about $9 \mathrm{p} . \mathrm{m}$. till midnight. No rehearsals were held on the Thursday evening of that week and on the eve of the anniversary itself.

Nightly the gamelan players assembled in the space between the main dining-hall, the Sasana Andrawina, and the main audiencehall (pendapa), called the Sasanasewaka. While waiting for the dancers to come out, the orchestra played the celebrated melodious gamelan Kjahi Kaduk Manis/Manis Rengga. While the orchestra played its overtures, the dancers suddenly appeared from

6. Programme of the Congress of the Java Instituut, held in Jogjakarta on December 24-27 (1924). Today the courts of the Mangkunegara (Surakarta) and the Paku Alam (Jogjakarta) have broken this tradition, due to their relationship with the two principal courts through dynastic marriages.

7. Hadiwidjojo, op.cit. 
inside the Dalem Prabasujasa.

For the rehearsals they dressed in dodot kemben (breastcloth), usually of dark brown batik, leaving the arms and shoulders bare, and njamping (bațik skirts) of the parang rusak gendrèh motif, arranged in the samparan style, the end of the skirt forming a long train falling between the ankles. Around their waists, tucked in the folds of the breastcloth and tied in front into a knot, were long cream-colored sashes. Edged with fringes of the same color and almost reaching the floor, these sashes or sonder are very often used to accentuate the various dance movements. The prescribed hair-style for the occasion is the gelung tekuk, a traditional style of ornamentation for ladies, artistically coiled and usually stuffed with fragrant shredded pandanus leaves and jasmine blossoms.

The instruments accompanying the Bedaja Ketawang were reduced to a mere seven, namely the Gong Ageng, kendang Gong or kendang ageng, ketipung, kemanak, ketuk and kenong. An important role was played by the choir, which consisted of about six female singers, led by three principal singers called lurah pasinçèn. The gamelan instruments were thus supplementary, providing the rhythmic beat and the colotomic structure.

Before the actual dance music began the musicians played an elaborate meditative melody called the pațetan. The instruments used for this soft and melancholy music are the rebab, gendèr and gambang. The dancers in the meantime took up the opening position of the dance (linggih rakit) (PI. 7) and waited for the right gong beat to begin their movements. It is interesting to note that unlike the more modern bedaja and serimpi dances, the Bedaja Ketawang has no keprak beat to guide the dancers, so that they have to listen and follow the sound of the large gong, the kemanak and the kenong. The more experienced dancers know the litany by heart and this also helps them should they miss a beat.

The Bedaja Ketawang consists of three parts and each part of the litany is initiated in turn by a different principal singer. These principal singers are actually court attendants occupying a higher rank than the ordinary singer (pasindèn lèdèk). They are the only ones left who are still steeped in the mandaraka singing style. Their small number-only three survive today--and their advanced age, make one very pessimistic about the continuation of this form of singing.

Due to the length of the dance and the intricacy of the movements, two dancing teachers sit on the floor acting as prompters, while three other ladies-in-waiting squat nearby, ready to adjust trains and drapery. 


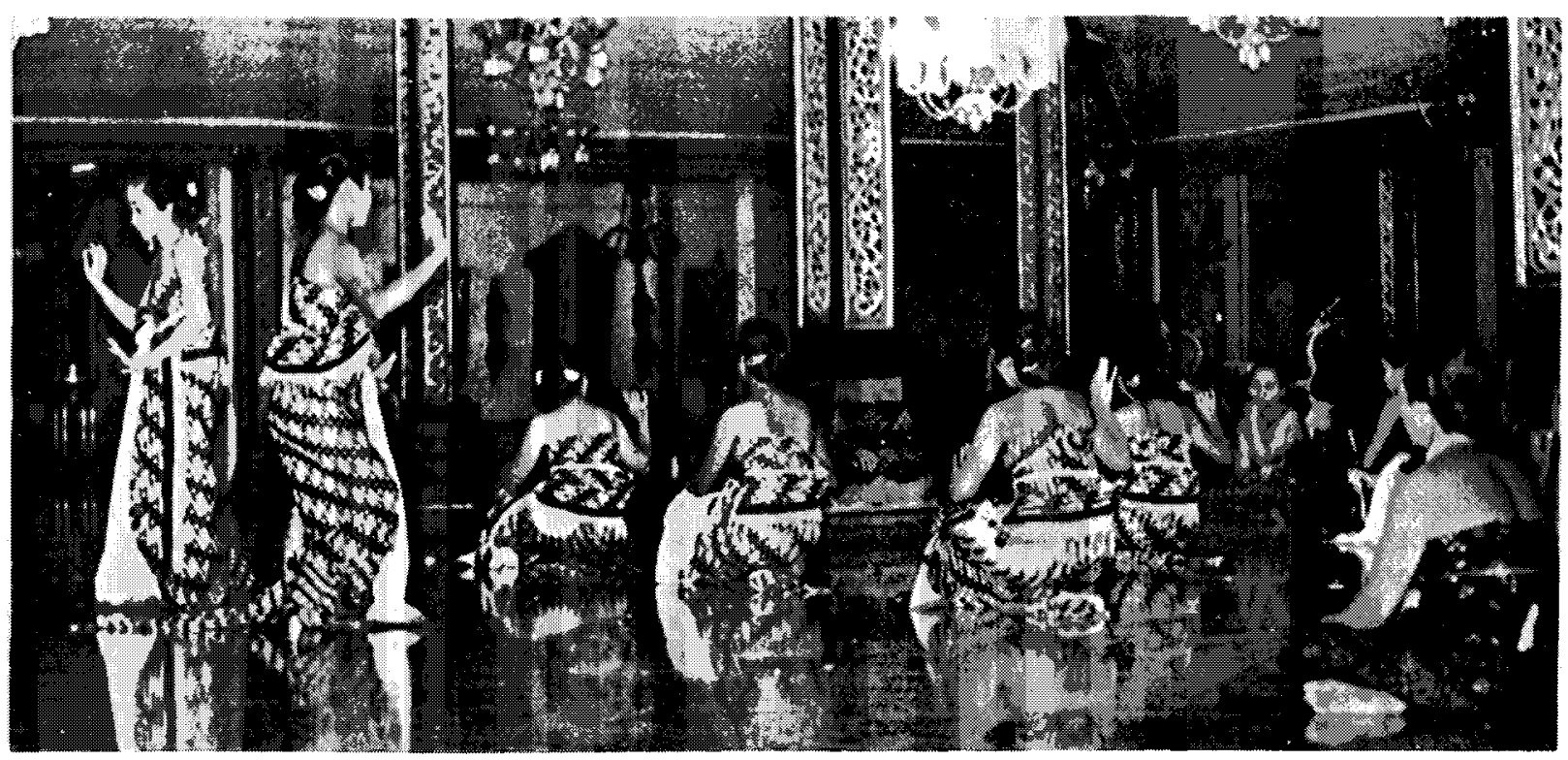

P1. 2. The Dress Rehearsal (see diagram d, p. 55).

Dress Rehearsal

The nightly rehearsals lasted for about six days, with the seventh night reserved for the dress rehearsal or kirap. On this particular night the dancers were differently dressed and made up. Instead of the breastcloth and batik skint they wore the kampuh with the parang rusak barong motif, elaborately and artfully draped over a bațik skirt with the parang rusak klitik motif, arranged in the samparan style with a long train. As before, arms and shoulders were left bare, the long sash was knotted in front and petals were inserted in the folds of the trains; thus with each kick of the train a shower of petals and wafts of fragrance reached the audience. The hair was still arranged in the gelung tekuk coil, except that the hairline was now shaved and shaped (kerik), since according to traditional belief, the Goddess of the South Sea was already present and watching the dance. The shaving of the hair was actually done in preparation for the bridal make-up worn for the official celebration. On that evening the Susuhunan was also present, sitting on his throne in front of the Dalem Prabasujasa. 
P1. 3. A moment during the dress rehearsal.
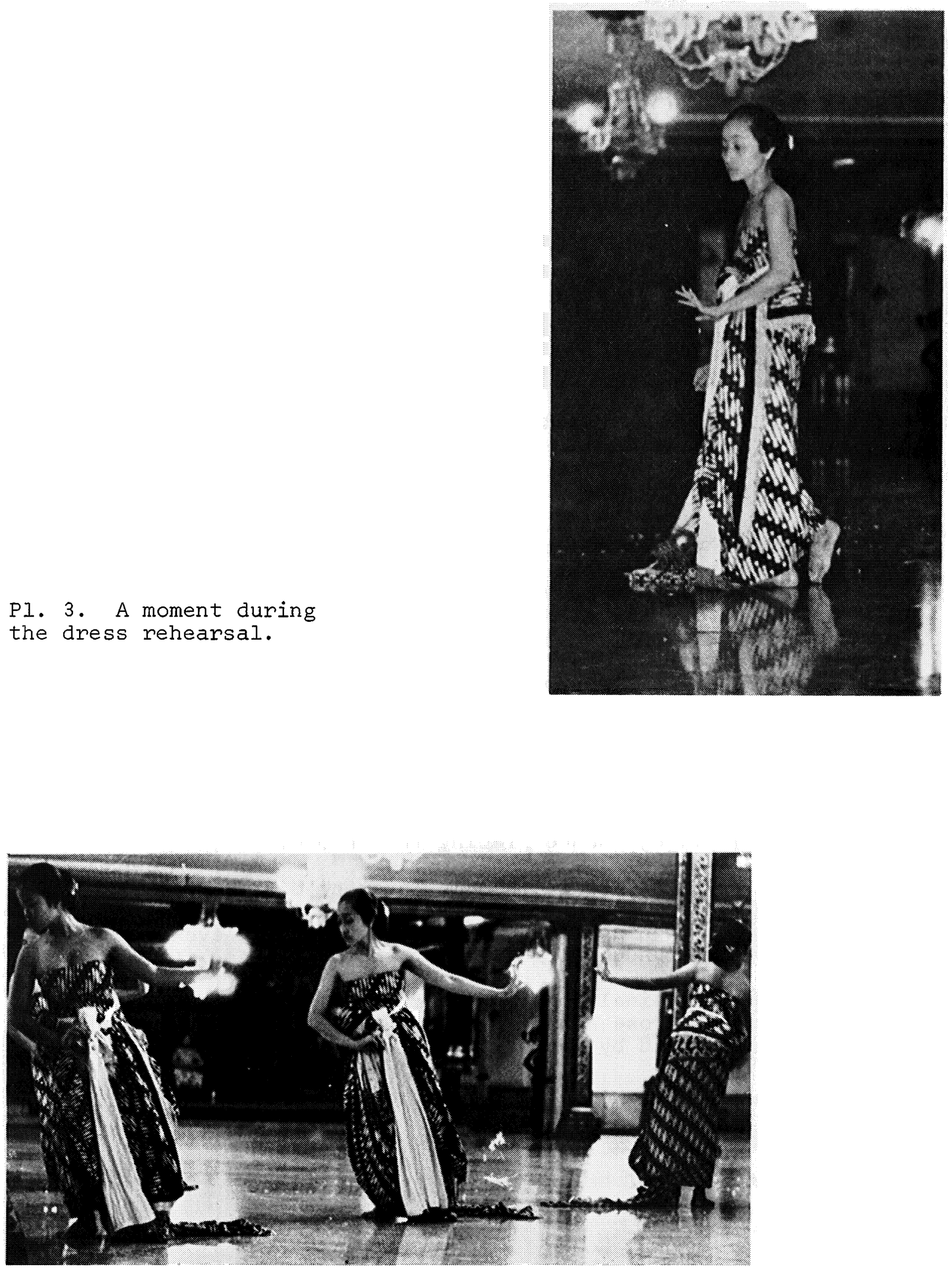

P1. 4. The Dress Rehearsal: the typical "undulation" effect. 


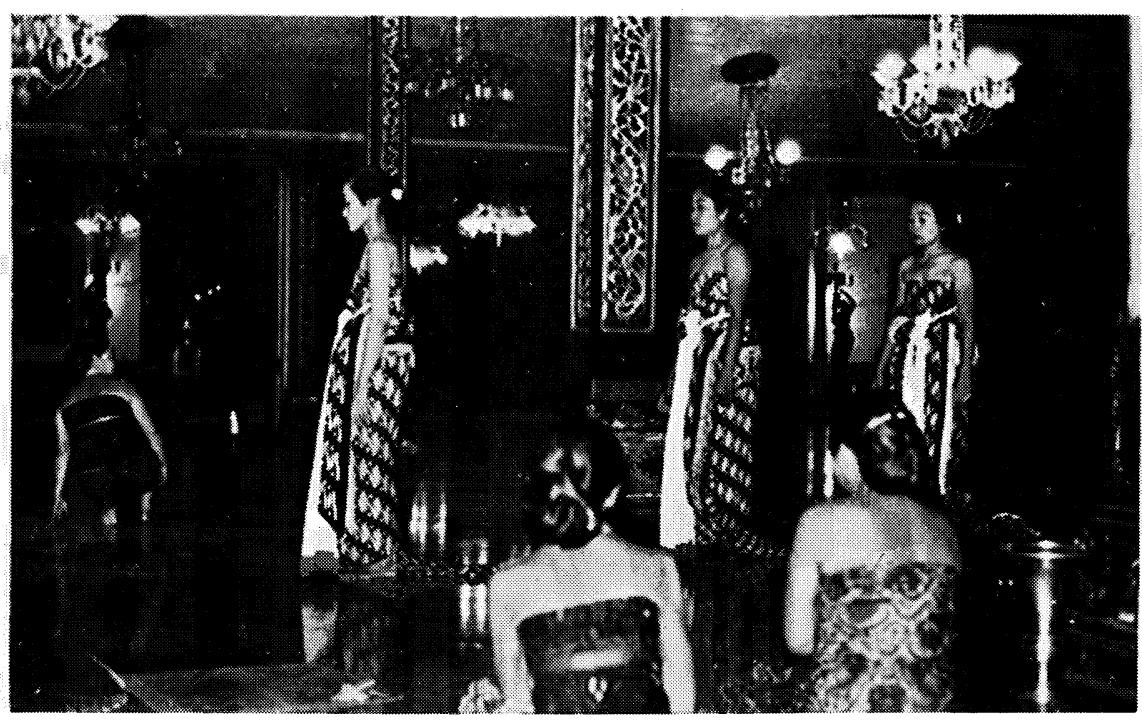

P1. 5. Dancers return to the Dalem Prabasujasa.

Unlike the previous nights, the dancers emerged from the Dalem walking slowly in single file ${ }^{8}$ (Pl. 1) towards the glittering pendapa Sasanaséwaka. Here the shrouds had been removed from the carved and gilded pillars and heavy crystal chandeliers, while the marble floor had been polished till it shone like a mirror. Strains of the patetan accompanied their gliding walk, while the solemn atmosphere was increased by the voices of a male choir under the leadership of a dalang, intoning the suluk, * a kind of introductory narrative.

Reaching the space between the four main columns (sakaguru) of the pendapa, under the main crystal chandelier, they stood for a while and then slowly sat down in the opening position of the bedaja dance ${ }^{9}$, facing the throne.

The movements of the Bedaja Ketawang differ from those of other bedaja dances in their more accentuated and exaggerated character. Watching the Bedaja Ketawang easily evokes associations with the undulating waves of the South Sea. (PI. 2-4)

After the final sonorous gong beat ending the dance, the dancers slowly rose and started their return towards the Dalem again accompanied by the strains of the patetan and the suluk. 10 (P1. 5)

8. See part III of this article.

* See Appendix I below.

9. Ibid.

10. See Appendix I, for the text of the suluk. 
No rehearsals were held on the day before the actual celebration. The dancers had already started their fasting and the sacred musical instruments were being made ready for the performance (djamasi).

\section{The Performance}

Activities on the morning of the celebration started at about ten o'clock. In one of the open pavilions on the outer rim of the inner courtyard opposite the main audience-hall, a welcoming gamelan (gamelan ujon-ujon) played melodies of greeting. Due to a shortage of gamelan players the men playing in the gamelan ujon-ujon later moved across to take their places at the gamelan Kjahi Kaduk Manis/Manis Rengga, when the time came to start playing the overtures. The musicians were dressed in short cut-away jackets, mostly dark colored, and baţik njamping, wrapped around and pleated, with daggers (kris) in their waist bands at the back and yellow samir around their necks. Some of the musicians had already moved to one of the outer courtyards in order to be ready to play the gamelan munggang later during the ceremony.

On a long table in front of the gamelan Kjahi Kaduk Manis/ Manis Rengga, two long rectangular tables were placed, laden with offerings. 11 All these offerings were said to be offerings for the Goddess of the South Sea, who, it is believed, would be present and would even participate in the dancing. For this special day some of the instruments of the Kjahi Kaduk Manis/Manis Rengga gamelan had been replaced with particularly sacred instruments. The two large kendang used were Kandjeng Njai Dénok and the Kandjeng Kjahi Iskandar. The names of the sacred rebab were Kandjeng Kjahi Grantang and Kandjeng Kjahi Lipur, while the big gong is called Kandjeng Kjahi Kemitir. The two drums and the rebab were kept in the Dalem Prabasujasa. Some time before the performance they were carried out by four female attendants, shrouded in the sacred red silk patola called tjindé. The large holy gong was kept in the Bangsal Balébang near the Sitihinggil. Incense was burned in little braziers, and bowls, filled with water and flower petals, were always placed near the instruments, while musicians or attendants always offered a sembah before touching them.

As soon as the Susuhunan was visible in the doon of the Dalem, the gamelan orchestra played the first bars of the Gending srikaton. This melody is always played whenever the Susuhunan makes an official appearance. On this day he wore a

11. See Appendix III for a complete list of the offerings. 


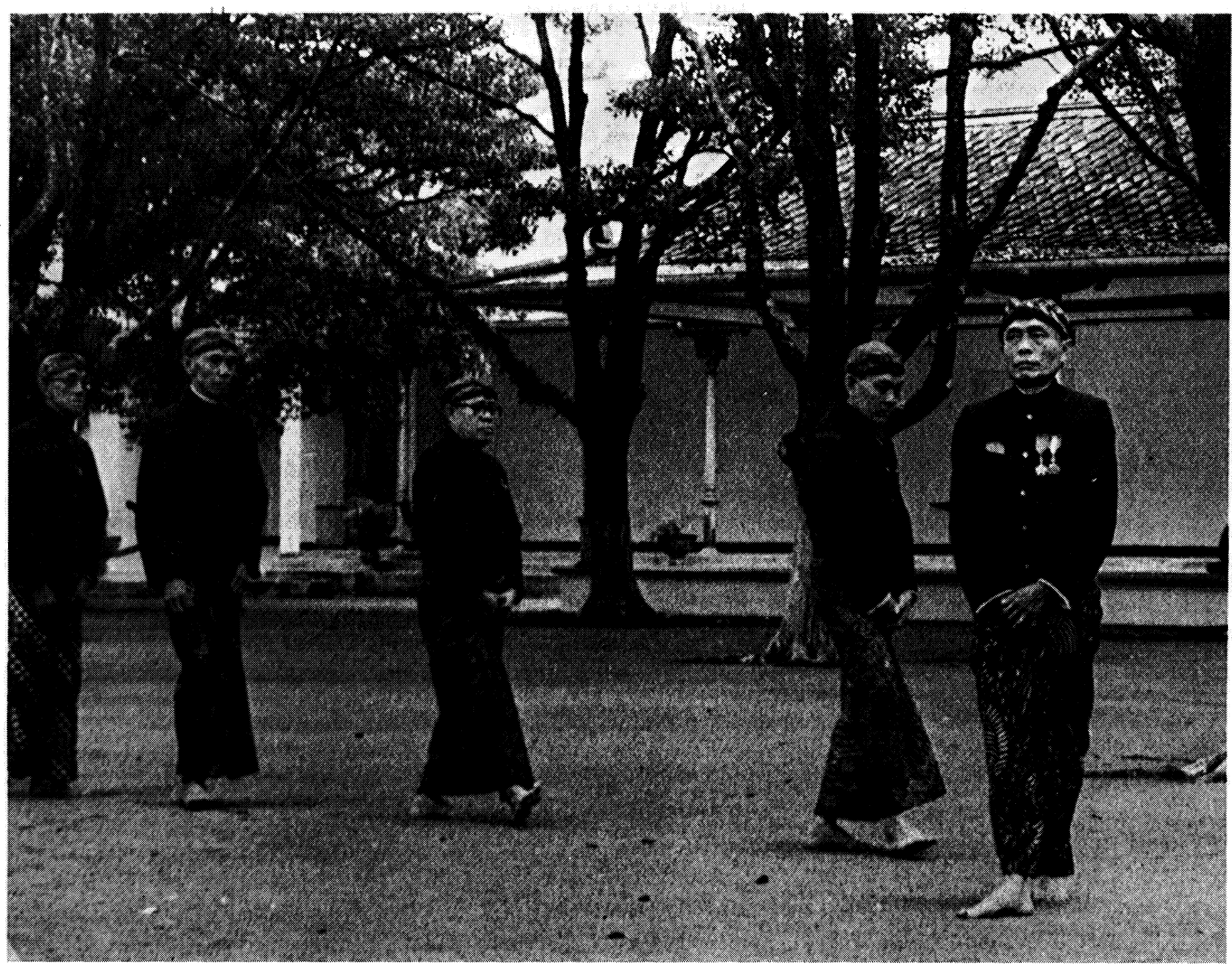

Pl. 6. Lower ranking courtiers entering the main audience-hall (pendapa). 


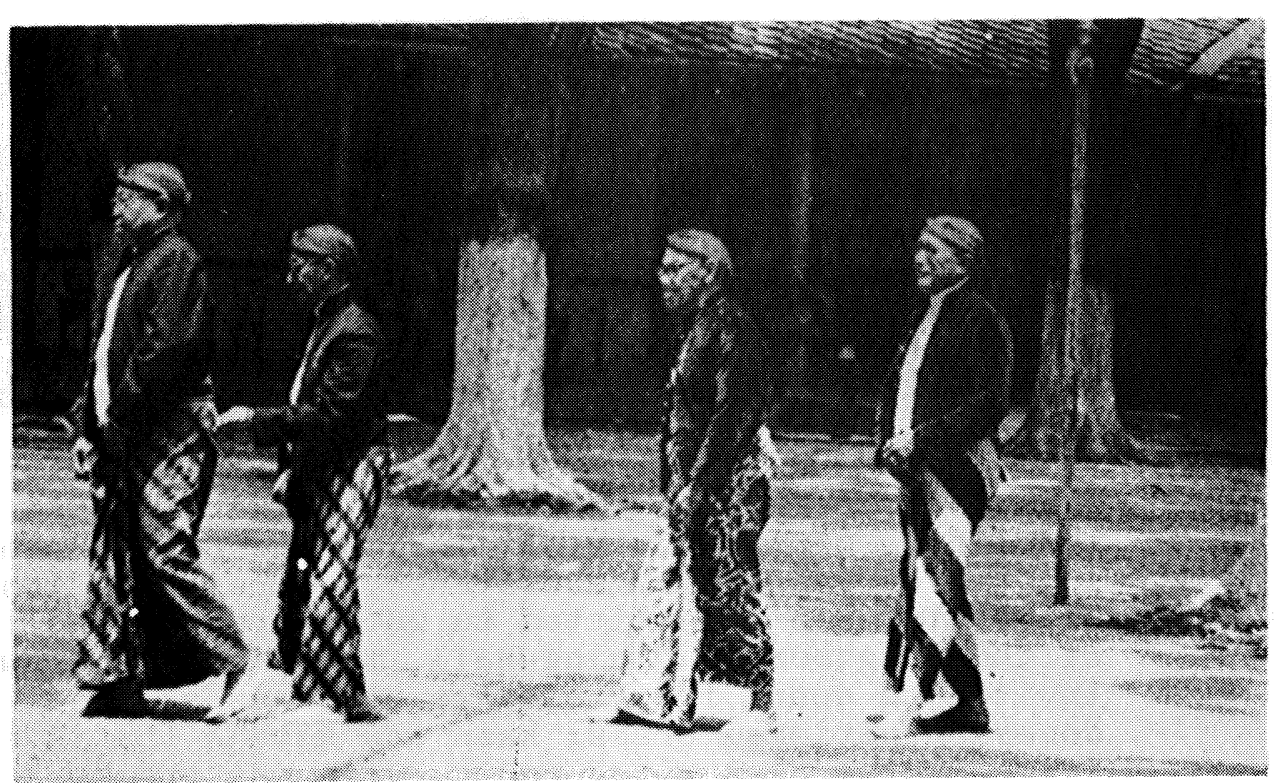

Pl. 7. On the morning of the anniversary.

Princes and senior court officials on

their way to the main audience-hall (pendapa).

P1. 8. The Njai Tumenggung

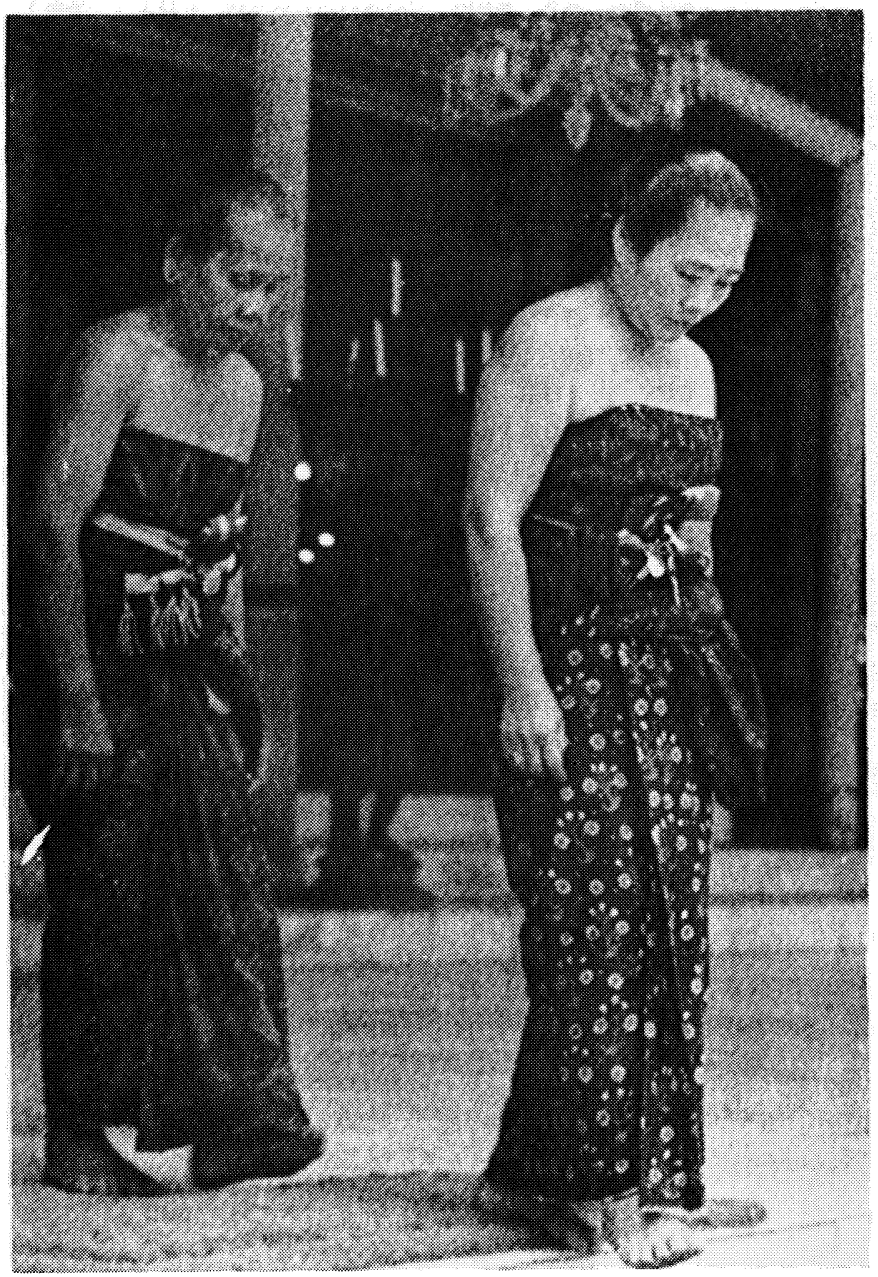
with attendant. 
dark blue velvet jacket and a black fez-like cap decorated with gold stripes, called the Kuluk Kanigara. He was followed by female court attendants carrying the sacred regalia, spears, shields, swords and spittoons. Sitting on a low stool covered with dark red velvet (Dampar Kentjana), he was flanked by little girls sitting on the fioor to his left and right, softly waving peacock-feather fans. The other female attendants sat behind him.

The ceremony on this day was mainly a men's affair. All the ladies of the court sat inside the Dalem Prabasujasa, watching the ceremony from a distance. Foreign ladies invited to the celebration were permitted to watch from behind the glass windows of the neighboring dining-hall, the Sasana Andrawina. Ladies invited to court functions are nowadays allowed to wear the Indonesian national dress, kain and kebaja (bațik skirt and blouse). Formerly the prescribed court dress was the breastcloth, batik skirt and the already mentioned gelung tekuk.

At a sign from a court attendant, the Pangéran (princes of royal blood) and higher ranking courtiers were invited to enter the pendapa. While the gamelan orchestra played the Gending Puspawarna, they entered and took their seats on the righthand side of the Susuhunan (PI. 7*).

A female court dignitary called $\mathrm{Njai}$ Tumenggung entered the hall, crouching on her heels (mlaku dodok), and finally sat on the floor in the center of the pendapa facing the throne. After making three sembah, she reported to the Susuhunan, speaking in a solemn half-chanted court language. The Susuhunan commanded that the sacred gamelan Munggang in the outer courtyard be played. Still on her heels, she left the pendapa after making the sembah three times once again. While the booming tones of the Munggang began to be heard, she reentered the audience-hall. (PI. 8).

New orders were given and again she withdrew crouching, this time to tell the lower ranking courtiers that they could enter the pendapa. These then entered in a single file while the Gending Wiludjengan was played (PI. 6). After they were seated two other female count attendants invited the remaining guests (government officials, military officers, and the corps diplomatique) to enter the pendapa.

It was also the Njai Tumenggung who received the order for the dance performance to start and after a short pause the soft tones of the patetan and the melodious suluk were heard. From inside the Dalem the nine bedaja appeared. Slow and stately they advanced in single file towards the pendapa, preceded by

* Although plate 7 should precede plate 6 , the editors gave precedence to plate 6 because it conveys more of the setting. 


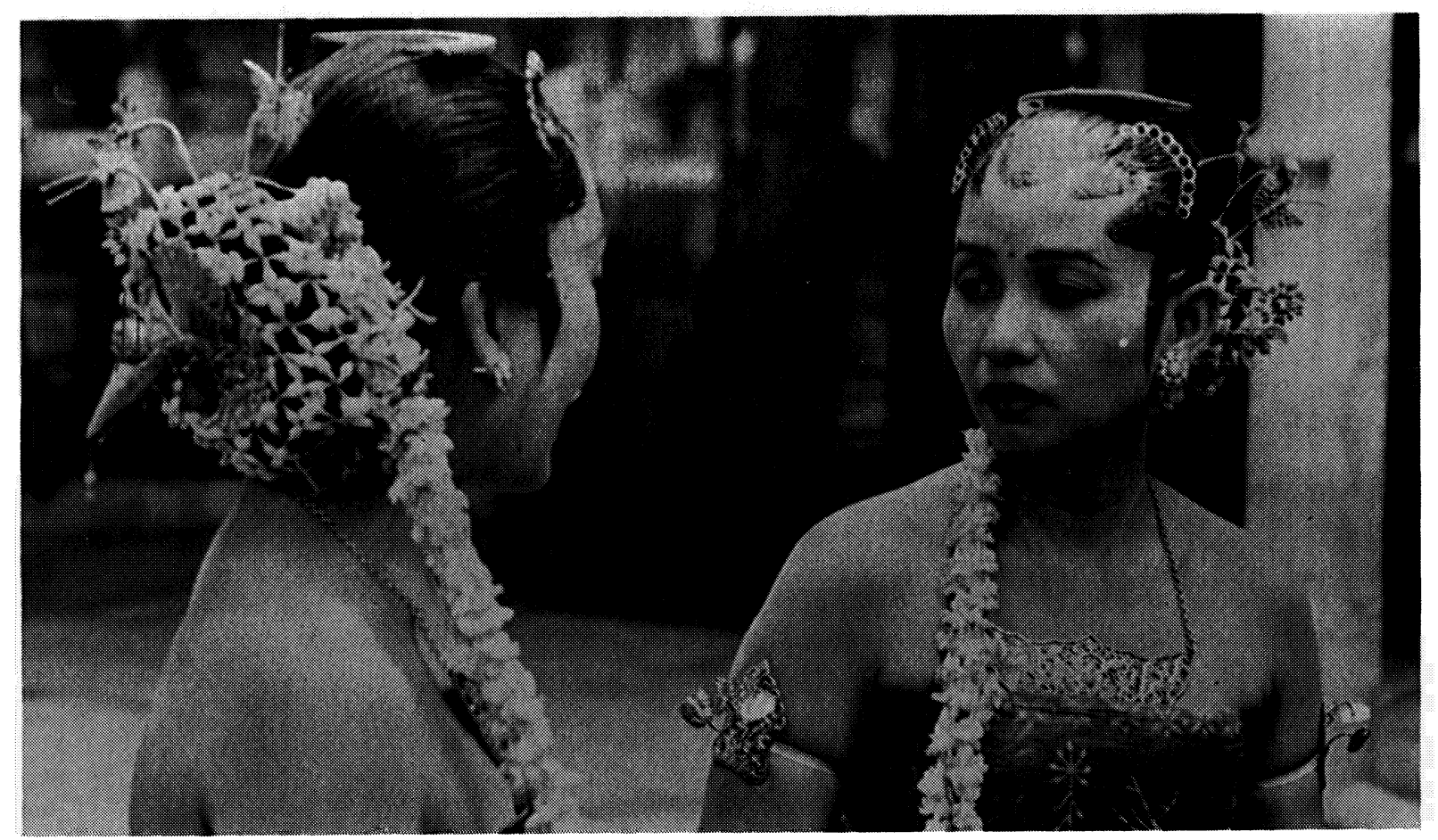

P1. 9. Bedaja Ketawang dancers in full ceremonial dress.

P1. 10. Beḍaja Ketawang coiffure and hair-ornaments, notably the Garuda Mungkur.

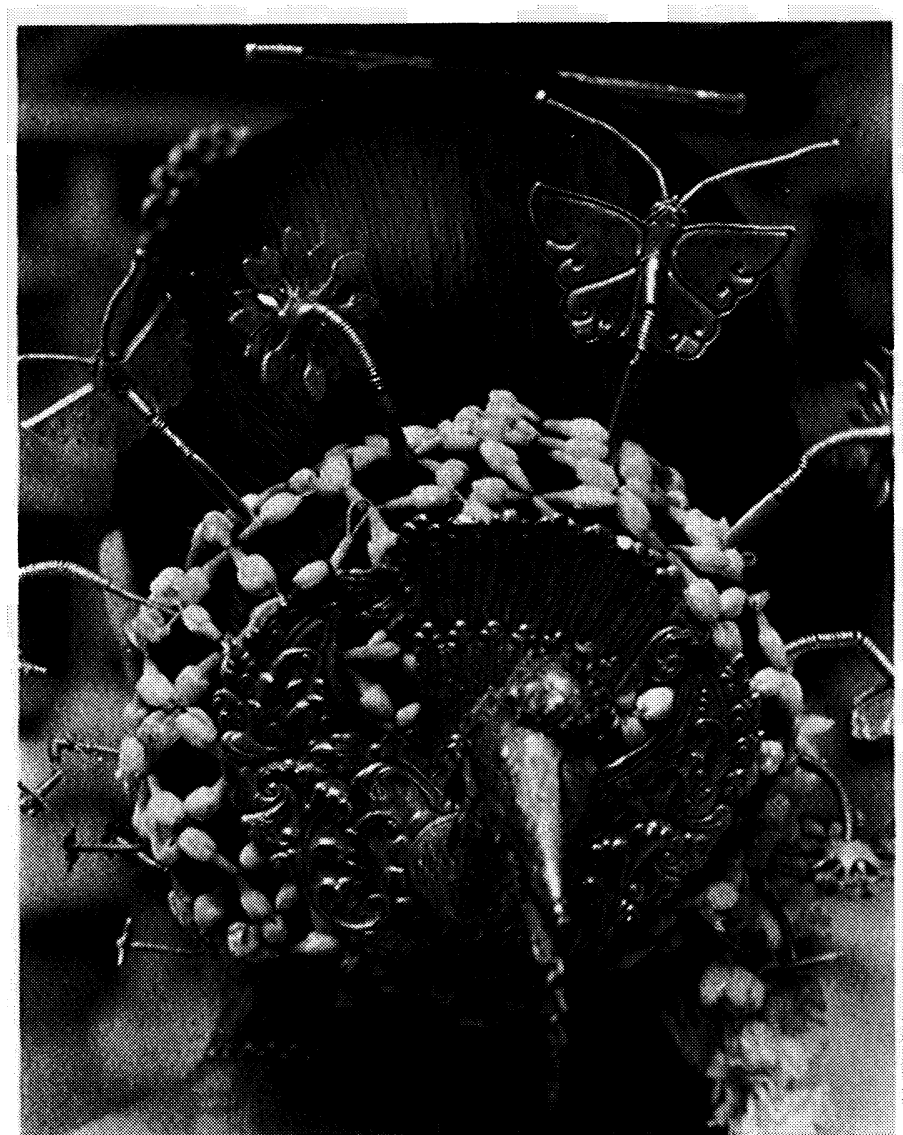




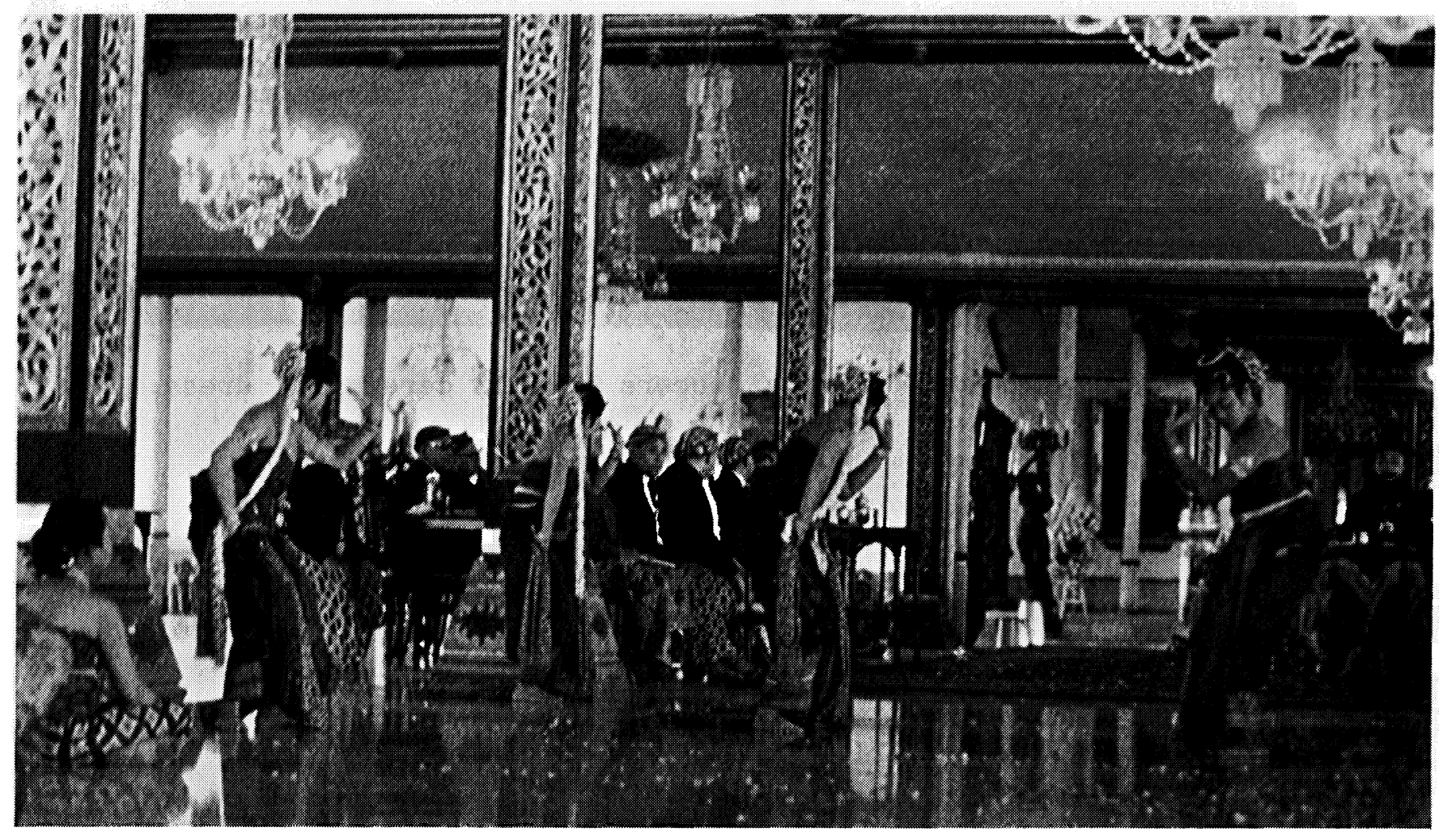

P1. 11. The Susuhunan Pakubuwana XII, seated to the right, watches the dance. 


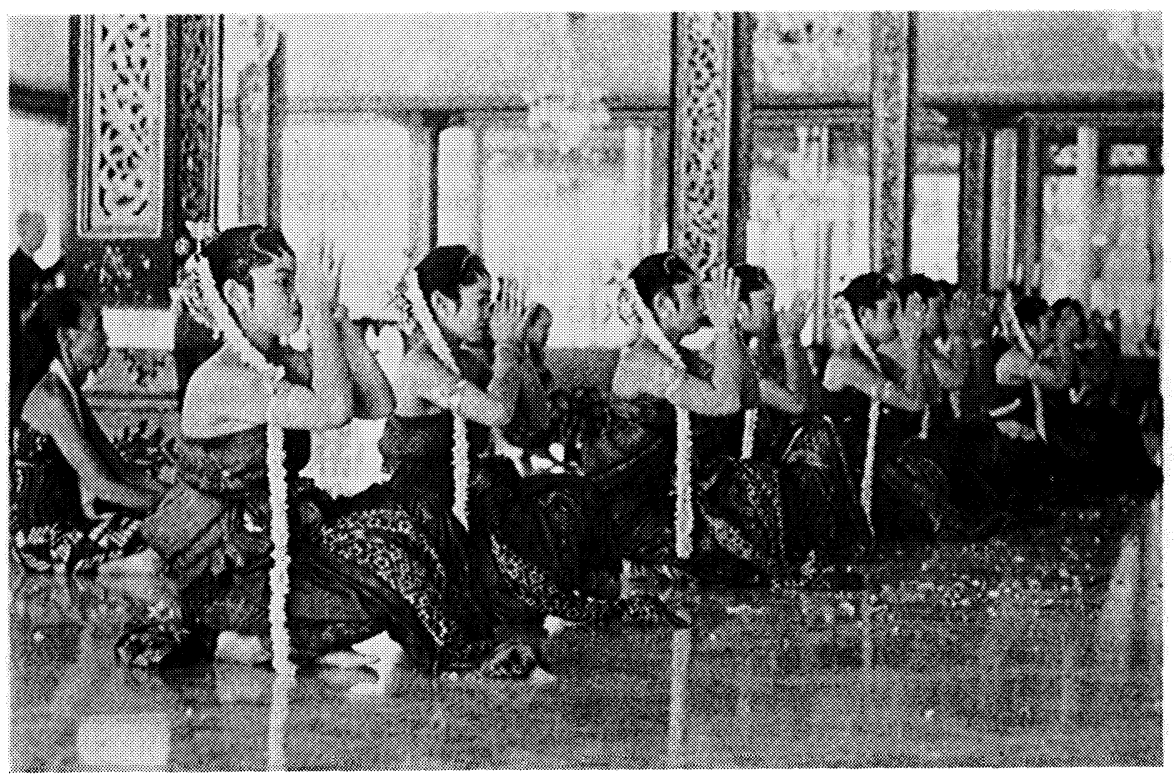

P1. 13. The dancers offer their

Sembah to the susuhunan.

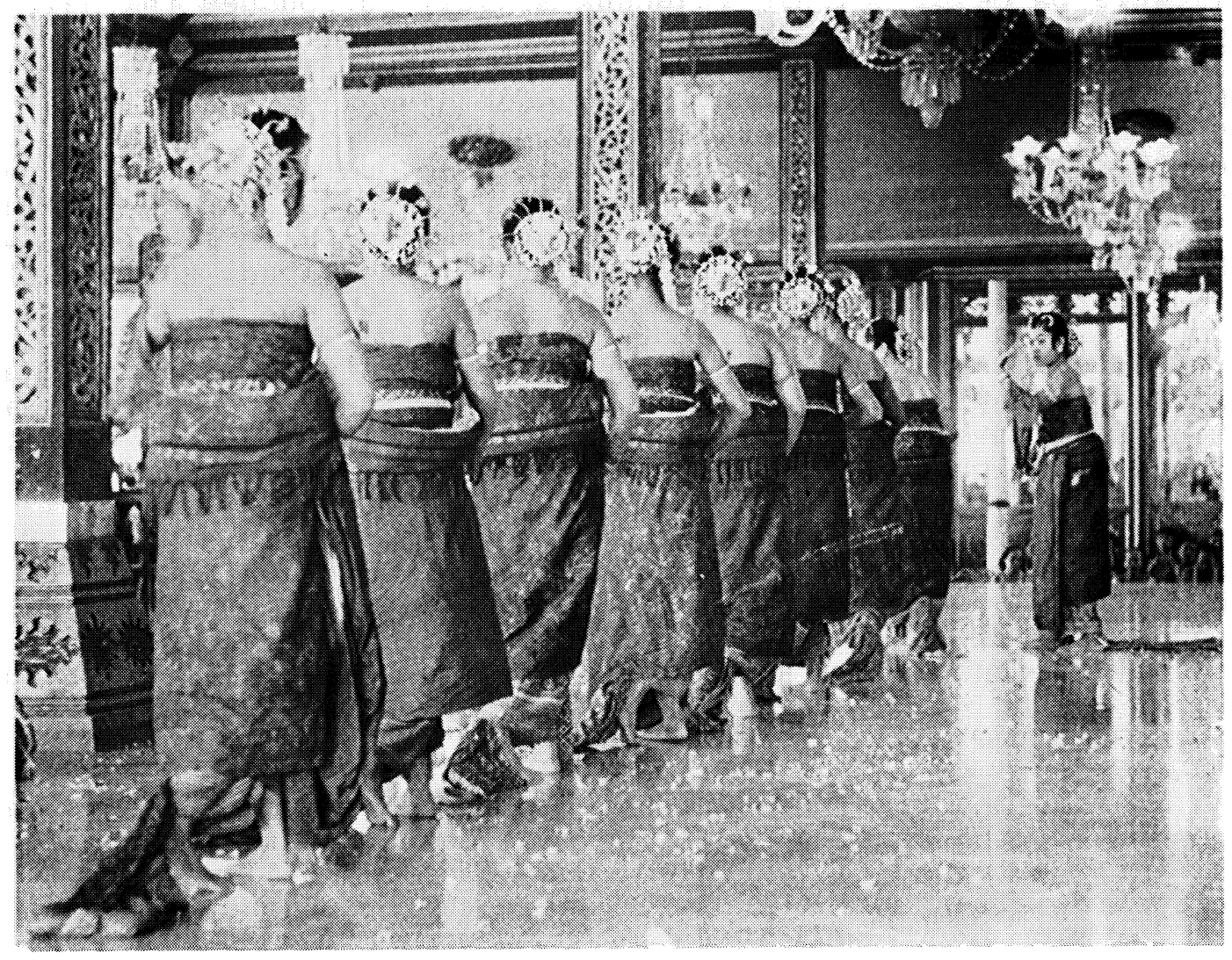

P1. 12. The dancers in formation (see diagram k, P. 54). 
a single female attendant crouching on her heels all the way, while two more followed behind the last dancer.

They passed to the rear of the throne, dressed now in their full splendor. The dark blue gold-embossed dodot alas-alasan was intricately draped over the wine-red tjindé cloth which trailed between their ankles. There were no cream-colored sashes this time, but rather full-length tjindé silks tied around their waists and clasped with a large diamond-shaped gold buckle in front. Heavy gold jewelry, such as armlets and bracelets, complemented crescent-shaped gold medallions (sang-sangan) hanging from their slender necks. Their faces and hairlines were done according to the classical surakarta court style of bridal make-up: the hairline accentuated and altered in shape with black wax (paès), drawn in a wide curve in the middle, and flanked by two triangular incisions and two shallow curves again at the temples, ending in a 'sideburn' (goḍèg) (P1. 9-10).

The haircoil was shaped in a style called gelung bokor mengkurep, round of form and wrapped in a hairnet of jasmine buds (rudji timun). In the middle of this haircoil, facing backwards, was a large gold center-piece in the form of a Garuda bird, the Garuda Mungkur. Quivering gold butterflies and flowers on metal spirals (tjunduk mentul) surrounded the haircoil, nine large ones and six smaller (PI. 10). Other ornaments included a pair of crescent-shaped hair decorations (tjentung), worn near the hairline and the tjunduk djungkat, a scimitarshaped comb, fastened horizontally. All these glittering gold ornaments were richly encrusted with precious stones. From the inner righthand side of the haircoil, a long garland of jasmine flowers hung down, almost reaching the knees (PI.9). Today's Bedaja Ketawang dancers do not wear the traditional garland of leaves called buntal, usually hung around the waist. No one could give an explanation as to why these garlands have fallen out of use. The eyebrows were shaped in a style called mendjangan ranggah (deer's antlers) and between the tip of the eyebrows a tiny diamond-shaped dot made of betel leaves was added, called laler mentjlok ( $\mathrm{PI}, 9$ ).

Moving slowly, with eyes downcast, the bedaja danced for about ninety minutes. The audience--except for the Susuhunan himself, who sat stiffly on his throne--watched in relaxed attitudes (P1. 11). Princes and courtiers whispered and murmured softly throughout the performance, sipping refreshments served prior to the dance. A heavy fragrance of incense and flowers permeated the whole audience-hall.

After the final sembah, which coinciled with the last heavy gong beat, the dance ended. The nine dancers rose slowly and silently returned to the Dalem, preceeded and followed by crouching attendants (PI. 14). Again the suluk and the patetan 
accompanied them until the last dancer had disappeared.

The Susuhunan then rose from his throne and while the Genging Tjalapita was played, he too returned to the Dalem, followed by his ladies-in-waiting. The official part of the anniversary was over. The guests adjourned and entered the dininghall where a lunch was to be served. The gamelan players also moved, in order to play the ancient gamelan Kjahi Semar Ngigel. Around three $o^{\prime}$ clock in the afternoon the festivities had ended and only scattered paper napkins and vacant chairs remained as silent witnesses of a beautiful and impressive ceremony at the Kraton of Surakarta.

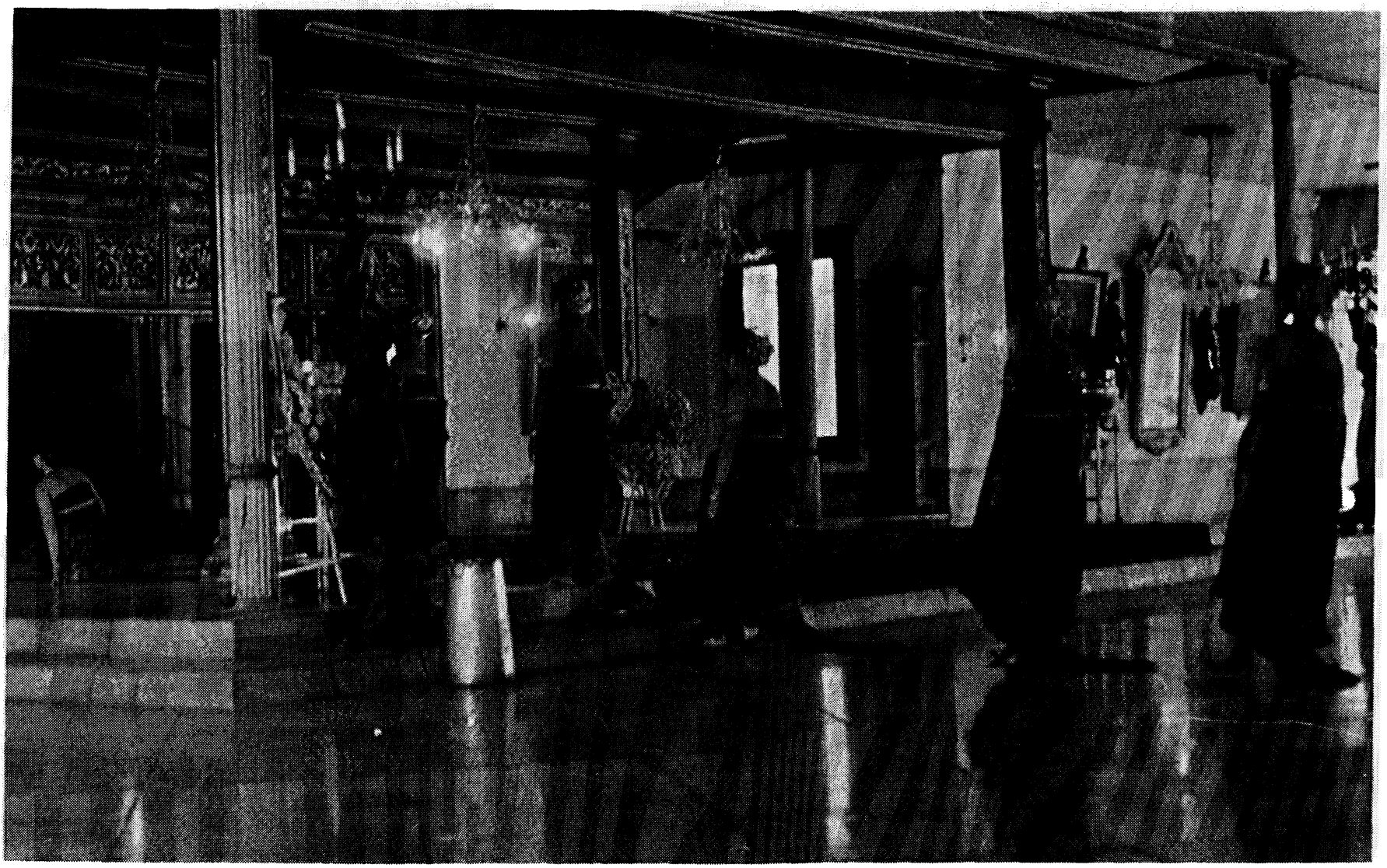

P1. 14. Bedaja Ketawang dancers returning to the Dalem Prabasujasa at the end of the dance, preceded by their attendant. 
Some choreographical illustrations of the main positions taken by the Bedaja Ketawang dancers is given below.

The order of appearance of the dancers when they emerge from the Dalem is as follows:
1. Èndèl.
2. Pembatak
3. Endèl Weton
4. Guiu
5. Dada
6. Buntjit
7. Apit Ngadjeng
8. Apit Wingking
9. Apit Meneng

In describing the dance positions the same order of numbering will be used while the point of orientation will be the Susuhunan's throne on the day of the anniversary itself.

\section{Part I}

a. The dancers are seated on the floor facing the throne (Iinggih rakit) and waiting for the third gong beat before offering their sembah and starting the dance.

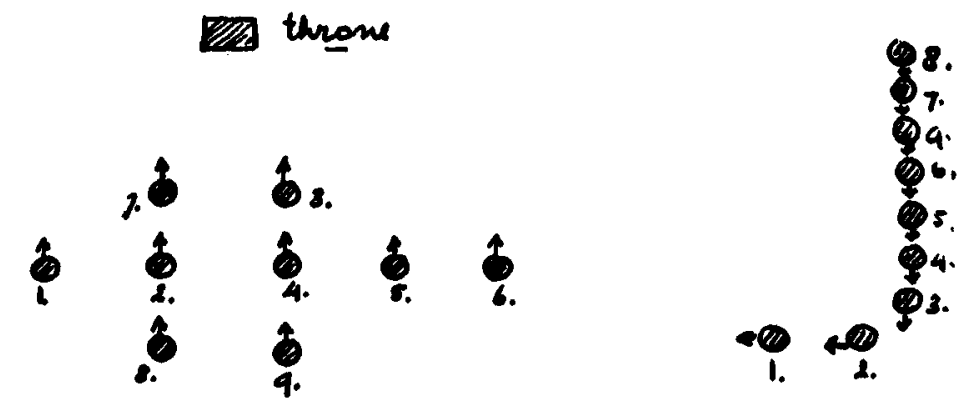

b. They remain in position a, but keep shifting angles (standing).

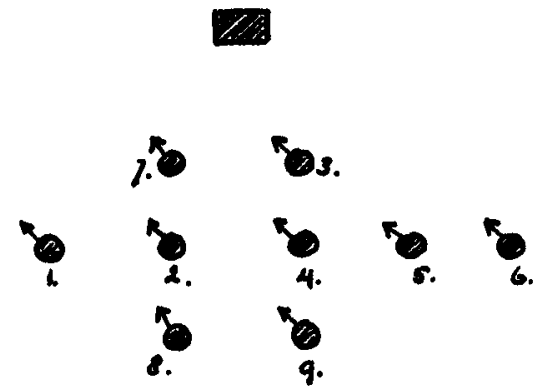


c. Change of position. Still facing the throne, the Apit Ngadjeng (7) and the Apit Wingking ( 8 ) move sideways as indicated by dotted line.

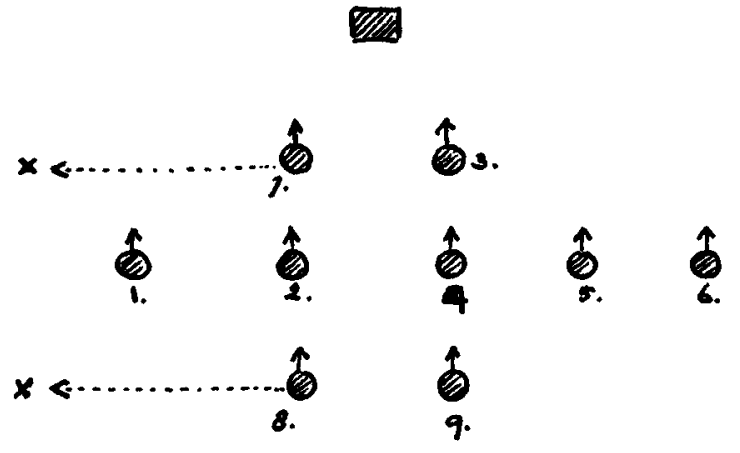

d. Position $\mathrm{c}$ is kept but the dancers face different directions.
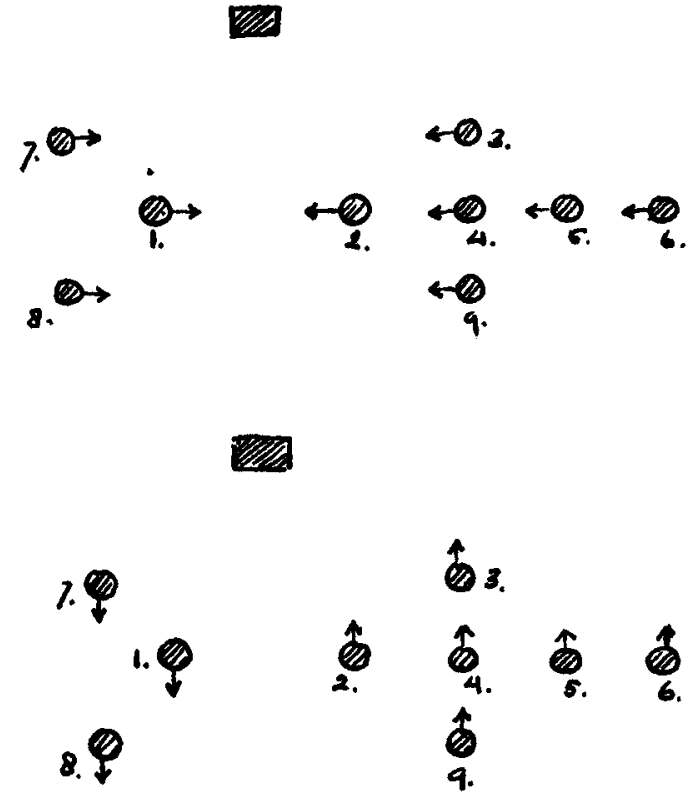

e. Same positions as above except that the Endêl (1), Apit Ngadjeng (7) and Apit Wingking (8) sit down, while all the others remain standing.

勿

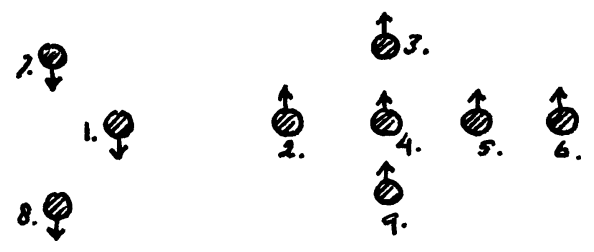


f. Transitional positions, in order to form a single file.
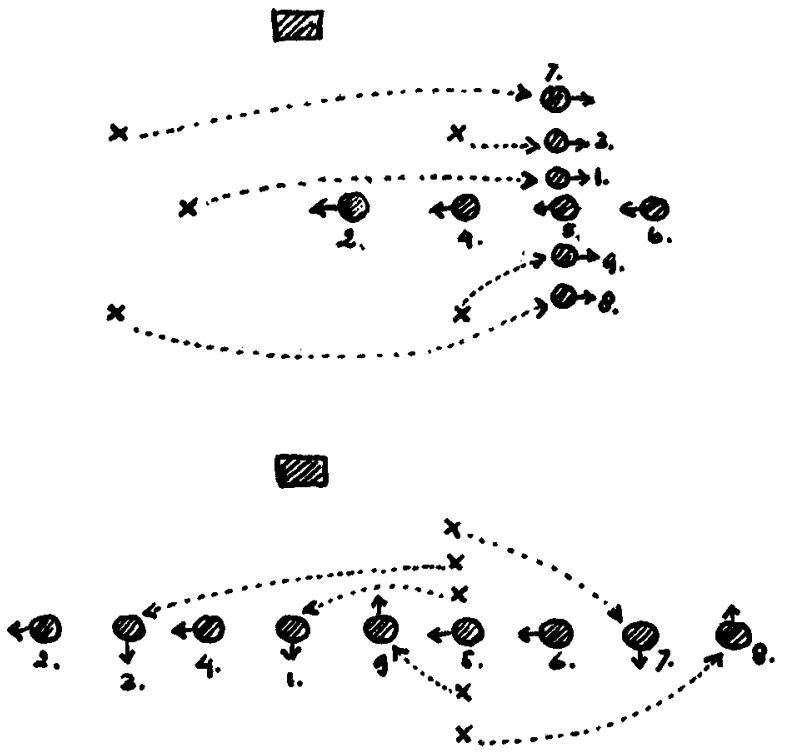

g. End of the first part.

All sit in a single file, facing the throne.

W

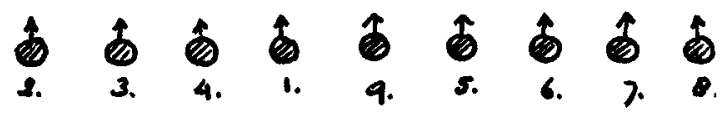

Part II

a. Same as end position of Part I, dance begins with the first gong beat.

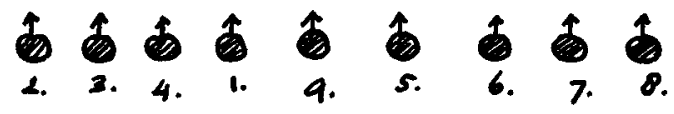


b. Change of poşition. Endèl weton (3) now takes over the role of the Endèl (I).

206

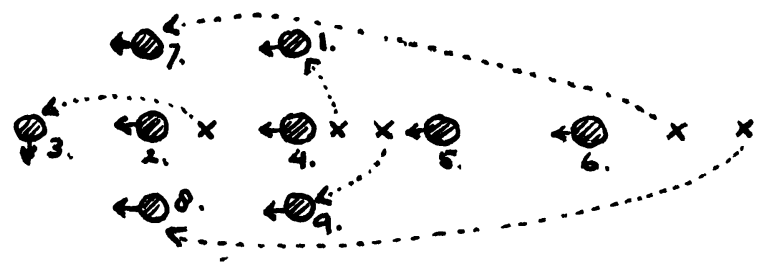

c. Same positions, only the dancers change direction several times and Apit Ngadjeng (7) and Apit Wingking ( 8 ) move sideways.
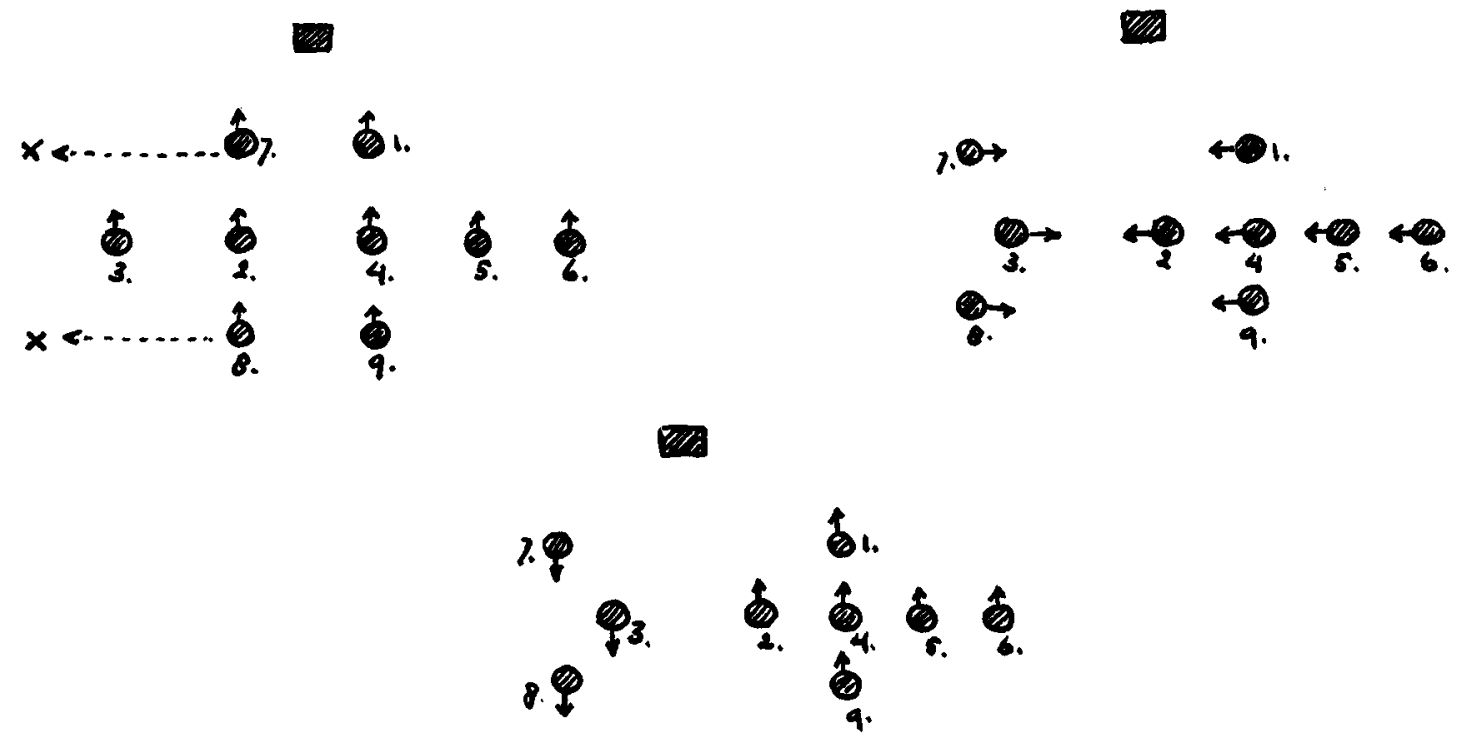

d. The Èndèl Weton (3), Apit Ngadjeng (7) and Apit Wingking (8) sit.

20.8

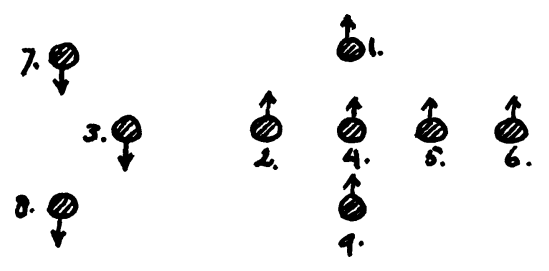


e. Again the formation of a single file.

\section{$\mathbb{Z}$}

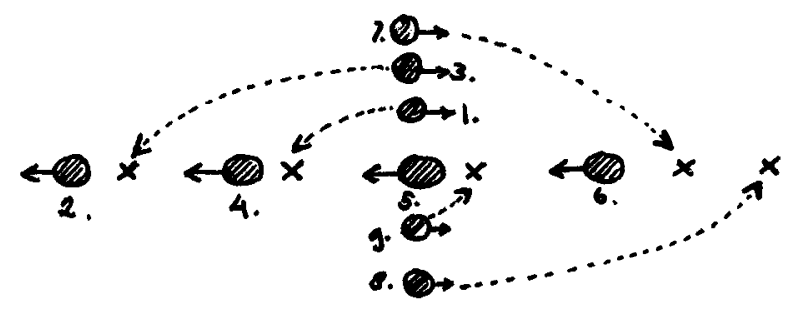

Wa

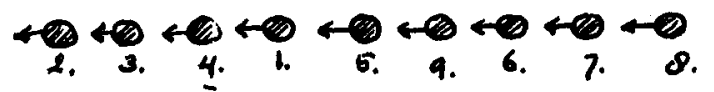

f. The Ëndèl (1) takes her former place and role vis-à-vis the Pembatak (2).

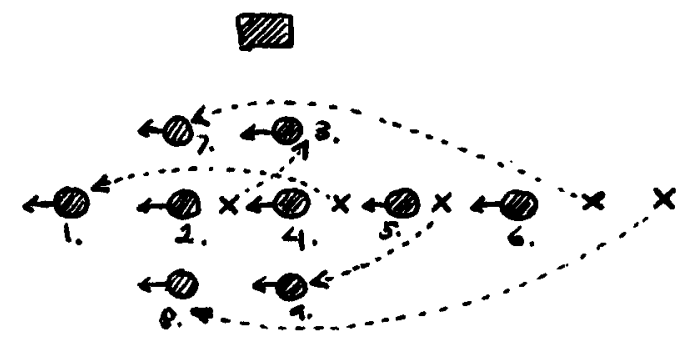

g. Single file formation.
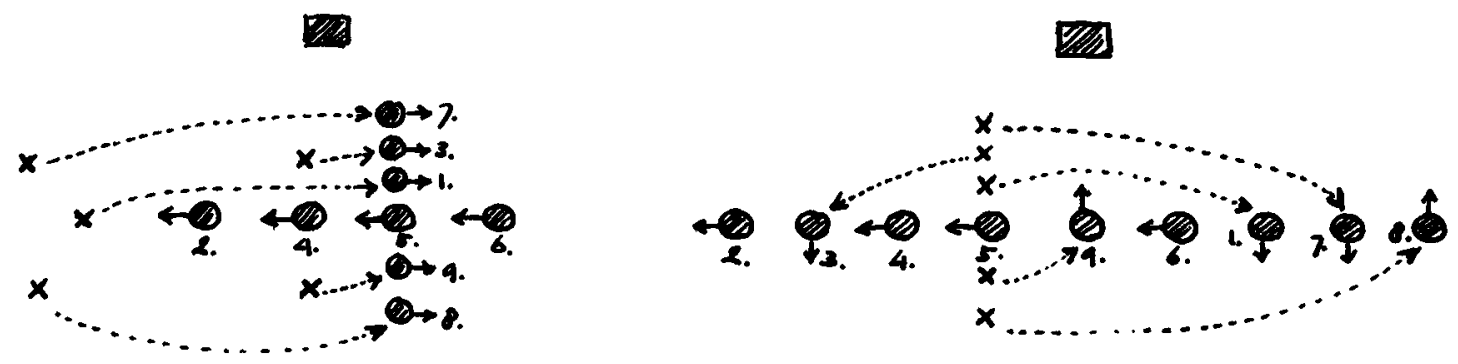
h. Change of position. Èndèl Weton. (3) again takes over position of Endèl (I).

प्र
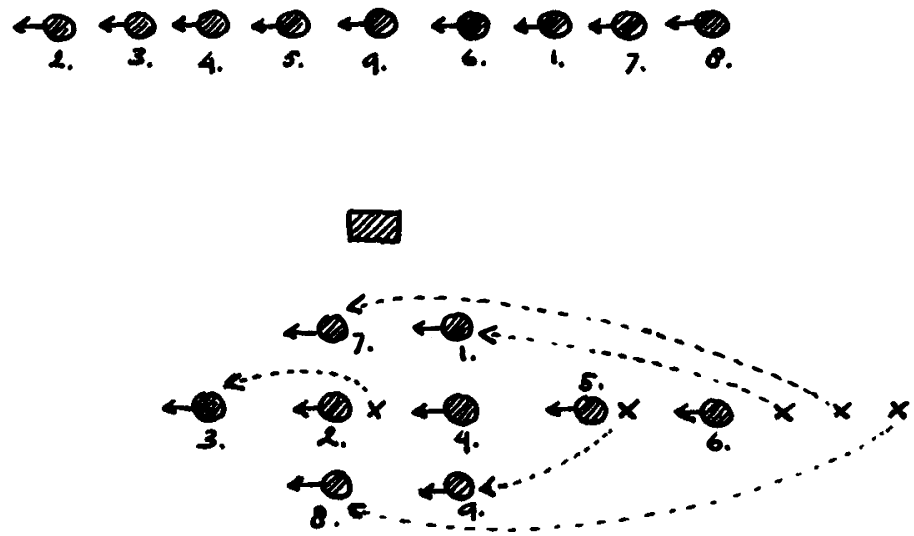

i. Position unchanged. Various angles, and Ėndèl Weton (3), Apit Ngadjeng (7) and Apit Wingking ( 8 ) sit, while all the others stand.

שד

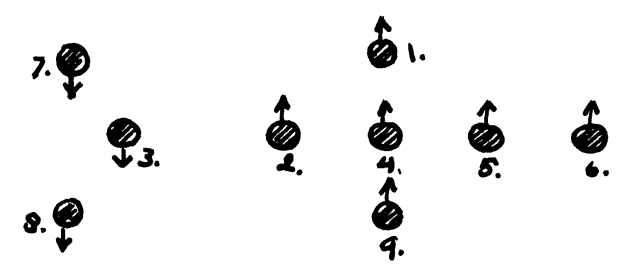

j. Single file formation.

$\mathbb{M}$

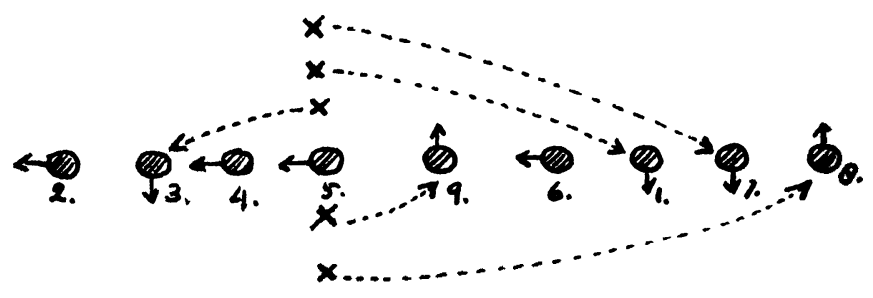


k. Final position. Pembatak (2) moves backwards until she reaches a position in front of them.

ש2]

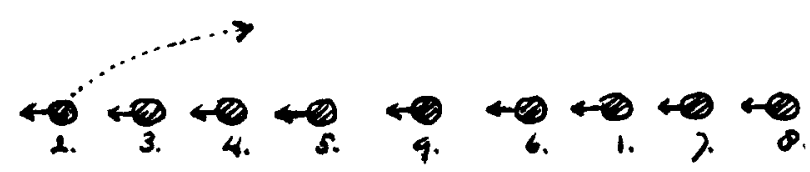

Wבת

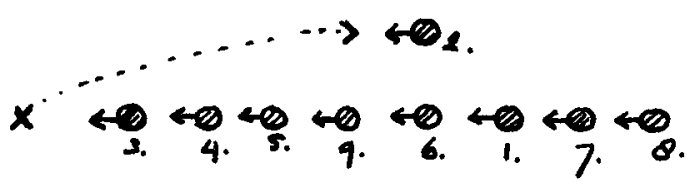

WI

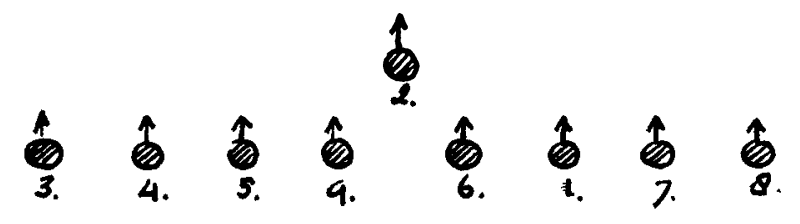

Part III

a. Opening position same as final position of Part II. Sembah coincides with the first gong beat.

Q

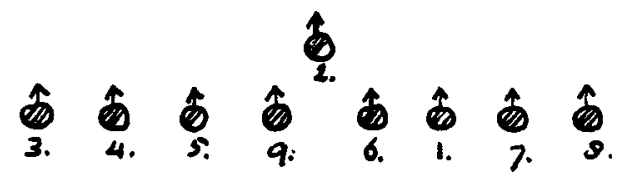

$\mathbb{Z}$

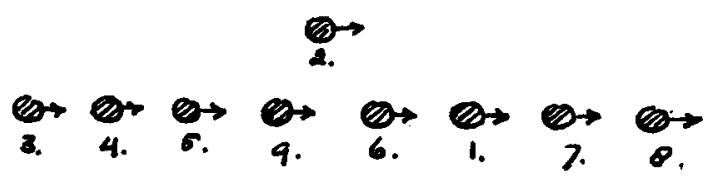


b. Change of position.

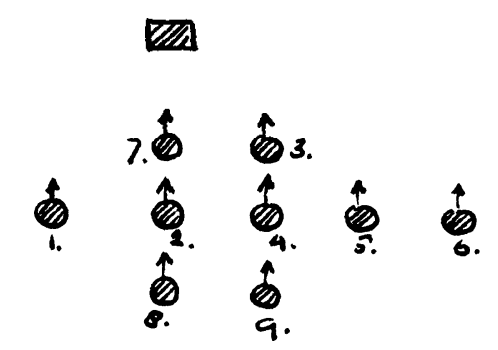

c. Same position, except that Apit Ngadjeng (7) and Apit Wingking ( 8 ) move sideways.

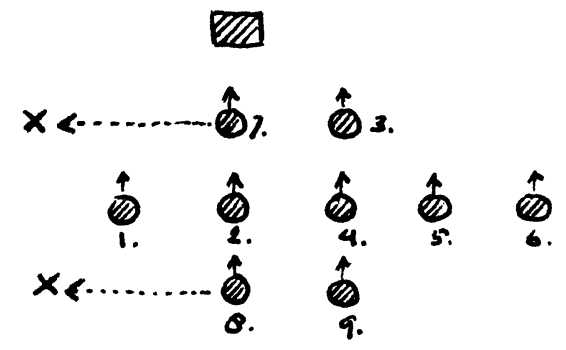

d. Position unchanged. All sit down except Pembatak and Èndièl, performing a kind of pas de deux.
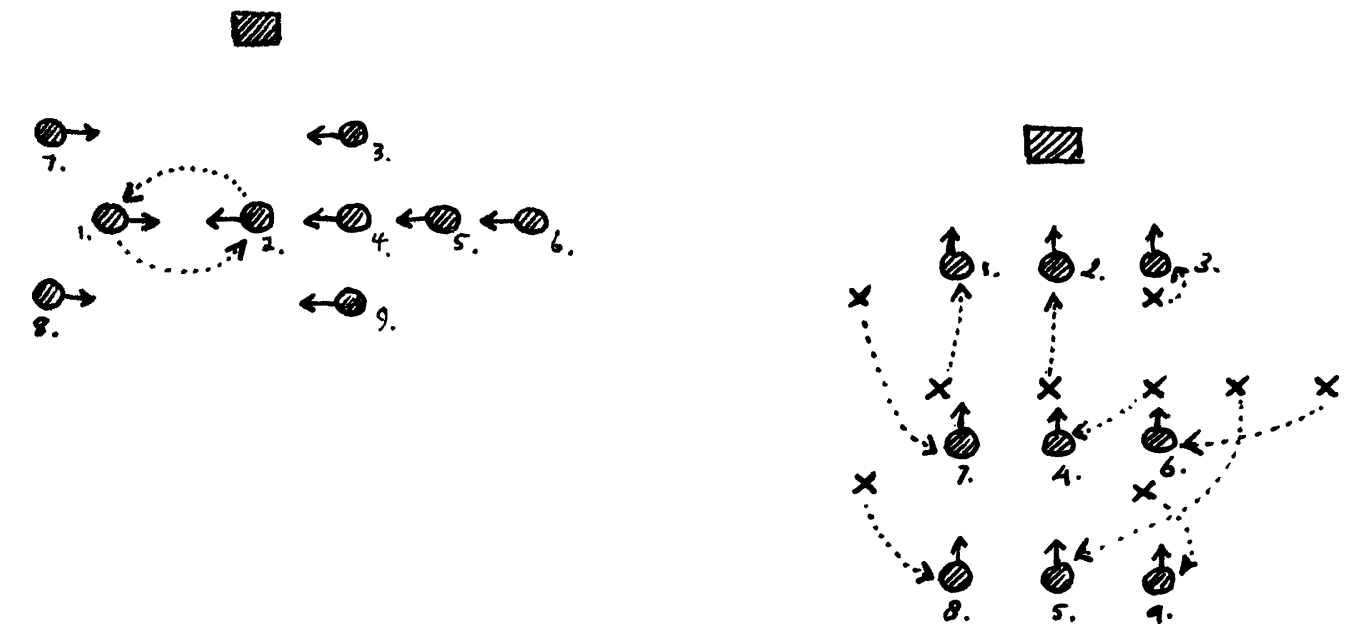
e. Change to final position. The dancers sit and make the Sembah. They leave when the pațet begins.

שִ

$\hat{\imath} \hat{b}_{1}, \hat{b}_{2}$

$\hat{i}_{7}, \hat{\otimes}_{4}, \hat{Q}_{6}$

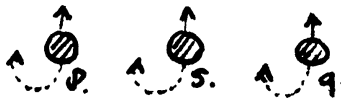

Return to the Dalem in single file in the same order as when appearing.

P

10
1. 


\section{Appendix I}

Suluk Pațetan Bedaja Ketawang as copied from the original in the collection of G. P. H. Soerjobroto.*

(Pélog pațet 5)

The following instruments are used for the pațetan:

$$
\begin{aligned}
& \text { 1. rebab. } \\
& \text { 2. gendèr. } \\
& \text { 3. gambang. }
\end{aligned}
$$

Singers chanting the suluk are all male. When the dancers emerge from the Dalem, the following words are sung: Midjil langenira Sanga prabu, lampahira alon (repeated

Dinarebeg baḍaja ju warnanira,

Sang nata mawingit, -.---

Lir hjang hasmara nurun, ----

Hjang tjandra purnamasidi,

Minangka dipaning wengi, Iintang hararas kumenjar, --.--

Djaladara dipaning sih, dipaning sih,

Katrangan pandyating kilat țațit,

Hanar natèng limut, -...- Riris handulur lan himur -..--

Rumning mulat, Surat sari -----

Rumning mulat, Surat sari -.--

Sari, sari, 00000 ------.

Accompanying the dancers returning to the Dalem, are these words :

Mundur langenira Sri Bupati, saking ngarsa katong (repeated Mangendjali Sri Nata linaras sami, solahira wingit,
widadari nurun --

Hasrining busana kadi, hanelahi rining wengi.

Kentjana retna sotya bra ---- hanglir mas murubing langit, murubing langit.

Katrangan sosotya hadi,

Kilat țatitira mbarung ---- riris handulur lan himur -----

Srining mulat, srining mulat, sarwasari ---- srining mulat, sarwasari -.---

Sari, sari, 000000

* The editors regret that they do not command sufficient expertese in Javanese to translate the above suluk and the litany in Appendix II. They would welcome receipt of translations from a competent specialist. 


\section{Appendix II}

Sinḑèn Beḑaja Ketawang Ageng

Words of the Bedaja Ketawang litany are copied from a manuscript owned by $R$. T. Warsodiningrat, concertmaster of the Court of Surakarta.

The first part of the litany is arranged according to the tembang Durma metrical form, while the second and the third parts are in tembang Retna Mulja.

Raka pakenira sampun, atengara,

Sira puniki kari, angling djajèngsekar, lah bapa tunuruha, tumulia tengara

nitir, sumreg hatata, sawaranja ngadjabsih.

Alantjingan pețak alus kampuh djingga, sabuk patola wilis, hakris tjinitreng mas, sengkang maniking toja,

binapanging mas angrawit, sekar tjepaka, gagonda hamrih minging.

Hakékatjé tjinḍé, binggel mas rinengga, ja urap urap sari, djamang mas tinatrab, ing retna adikara, asumping swarna

lan ruming, sumarsana bra

sumer gandanja amrik.

(Munten mungel malih ladrangan)

Semang semang diuh, asaréa let guguling, déwa darat apit apiting gapura, kadrawasan guguling aglaring djogan, ning wong Agung Susuhunan.

Sapa baja kang awelasan ing branti, ning wong Agung Susuhunan duh, pandamingrat kusuma didanur wếnda, ning wong Agung Susuhunan

kawistara nanging sira ing papréman, ning wong Agung Susuhunan.

Danumadya, dụ, ambaro lali sih djiwa, ning wong Agung Susuhunan

dèn asamar awita anuwun pada, ning wong Agung Susuhunan.

Leléwané jèn prapti nggeteri ati, duh, ning wong Agung Susuhunan.

mijanggalit randaning sira tilarsa, ning wong Agung Susuhunan

dèn aririh sarira sapa darbéja, ning wong Agung Susuhunan. 
Poma poma dụh, jèn babar adja nglingsiri, ning wong Agung Susuhunan

tuduhna nggèn manira angawula, sun anuwun pada baja, ning wong Agung Susuhunan,

sumbalinga jèn katona dadi lara, dadi édan baja, susuhunan.

Kapan baja wong Agung, babo sun amanggih ing papréman, ning wong Agung Susuhunan,

balé atmatundjung alit sinaredja, aģuh lamun kangen tumuntur pundi paranya.

Saturuné, wong Agung babo, ing papréman, premadya tangis, nimbok dangur susuhunan, sinawésa, aḍuh saraga temah wijoga, mbok

langak temah wijoga, tan appanggih, jèn mboja, sarana djiwa.

(mungel malih ketawang)

Babagusé, wajuha sanambang, dé sindura pinipis pinḍo, susuhunan, dé, anglawat akèh rabiné, Susuhunan, dé, anglawat kațah garwané, Susuhunan, dé, sosotya aglaring méga, Susuhunan, dé, kadi lintang kuwasané Susuhunan.

Ana nagis tumengènging tawang, ndé, kadya lintang pakartiné, panembahan.

Tanuwastra, kadita ageni, dé, urubé kantar kantar kijai, dé, jèn mati ngendi

surupé, jèn mati pundi surupé kijai.

\section{Appendix III}

List of offerings for the Bedaja Ketawang dance on the day commemorating the accession to the throne of $\mathrm{H}$. H. Sri Susuhunan Pakubuwana XII, on November 15, 1966.

The offerings are placed in silver trays on long rectangular tables in front of the gamelan orchestra (on the lefthand side).

Tray I contains: la. Paningset (waistband), sabuk (belt) and a destar (headcloth) of the color gadung bjur (green).

b. A pair of kampuh djingga (orange ceremonial cloth). 
a. Paningset pandan bineţot (green tieand-dye coloring).

b. Destar of the same color.

c. Bațik cloth with the Tjangkring pattern.

3a. Paningset rintik idjo (green dots).

b. Desțar of the same pattern.

c. Bațik cloth with the pattern Parang Rusak Barong.

Tray II contains:

la. Semekan (breastcloth) idjo bjur (plain green).

b. Semekan djingga bjur (plain orange).

c. Semekan udaraga.

2a. Semekan dringin (made of handwoven silk).

b. Bațik cloth with the pattern Limar.

3a. Semekan rintik majang mekar (dotted).

b. Batik cloth with the pattern Tjakarajam.

4a. Semekan wajuha.

b. Plain lurik cloth.

a box with: 1. Abon-abon.

2. Djungkat (comb).

3. Suri (fine comb).

4. Katja (mirror).

5. Ratus (incense).

6. Lisah djebadan (oil).

7. Tasik pupur (powder-box).

8. Lisah sepuh (oil).

9. Lisah tjendana (sandalwood oil).

10. Lisah tjampur bawur (various oils mixed).

11. Waring (hairnet).

12. Séla (frankincense).

13. Sekar (flowers), gantèn (betelnut leaves), ses (cigarettes).

Tray III contains: a. Singep (cover) plaid patterned. 
b. With underneath: djadjan pasar (assortment of cakes) and tumpeng menggana (spiced rice shaped like a cone).

Tray IV contains: Singep majang mekar covering entèn-entèn ketan biru (black sticky-rice cakes).

Tray V contains: Singep mantèn anjar, covering black stickyrice cakes.

Tray VI contains: Singep panḍan binețot with black stickyrice cakes underneath.

Tray VII contains: Singep bangun tulak (with a plain diamondshaped center) covering nasi wuduk (rice boiled in coconut milk).

Near a pillar another offering covered by a cloth of the banguntulak design with underneath a tumpeng menggana (rice cone). 